\title{
Implementasi Sistem Merit Dalam Manajemen Aparatur Sipil Negara Kementerian Agama Sulawesi Selatan
}

\author{
Andi Sefullah ${ }^{1}$ A. Muin Fahmal \& Muhammad Fachri Said \\ ${ }^{1}$ Magister Ilmu Hukum, Universitas Muslim Indonesia, Indonesia \\ ${ }^{2}$ Fakultas Hukum, Universitas Muslim Indonesia \\ Koresponden, Email: andisaefullaho7@gmail.com
}

\begin{abstract}
ABSTRAK
Undang-undang No.5 Tahun 2014 tentang Aparatur Sipil Negara (ASN) merupakan wujud dari kelanjutan pelaksanaan Reformasi Birokrasi, menuju profesionalisme pegawai. Merit sistem merupakan cerminan manajemen kepegawaian yang profesional dimana penempatan pegawai dan pejabat menggunakan kompetensi kinerja dan track record sebagai alat ukur pengangkatan Tujuan penelitian ini untuk mengevaluasi implementasi sistem merit dalam Manajemen ASN pada Kantor Wilayah Kementerian Agama Prov. Sulawesi Selatan dan melihat faktor-faktor yang mempengaruhi implementasi sitem tersebut. Penelitian ini merupakan penelitian normatif empiris dengan menggunakan pendekatan kualitatif dengan tujuan mengetahui bagaimana implementasi sistem merit dalam manajemen ASN serta faktor-faktor yang mempengaruhi implementasi tersebut. Sehingga diharapkan dapat memberikan sumbangan pemikiran terhadap pemerintah dalam pengkajian dan pelaksanaan sistem merit kearah yang lebih baik
\end{abstract}

Kata Kunci: Sistem Merit; Manajemen; Aparatur Sipil Negera

\begin{abstract}
The implementation of the Act Number 5, Year 2014 on The Civil State Apparatus is entity of a sustainable successful implementation of bureaucracy reform head to officers professionalism. The Merit System is a reflection of professional staffing management. The merit system is performance assessment based on work performance. The purpose of this research is to evaluate the implementation of merit system to officers development according to the needs of South Celebes Regional Office the Ministry of Religions and the factors affecting of its implementations. It is a normatif-empiric method with qualitative approach. It is hoped to describe the implementation of merit system in civil state management and and the factors affecting of its implementations. So that it is expected to contribute ideas to the government in the study and implementation of a better Merit System.
\end{abstract}

Keywords: Merit System; Management; Civil Servant 


\section{PENDAHULUAN}

Salah satu tuntutan dan amanat gerakan reformasi di Indonesia adalah mewujudkan pemerintahan yang baik dan bersih (Fernanda, 2005). Sampai dengan saat ini, birokrasi pemerintahan tetap menjadi hal yang menarik untuk dicermati, karena kondisi dan bahkan berbagai macam isu publik (public issues) mengenai birokrasi yang berbau miring (Yudiatmaja, 2015). Birokrasi di Indonesia sering dianggap birokrasi yang statis, dimana kurang peka terhadap perubahan lingkungan sosialnya dan cenderung resisten pada pembaharuan (Sirait, 2018). Sehingga berpotensi menimbulkan mal-administrasi yang menjurus korupsi, kolusi dan nepotisme (KKN). Selain itu, birokrasi di Indonesia belum mampu untuk mendorong terciptanya situasi dan kondisi yang kondusif bagi para investor untuk berinvestasi dengan cepat, nyaman, mudah dan aman (Zuhro, 2016).

Aparatur Sipil Negara mempunyai peran yang amat penting dalam rangka menciptakan masyarakat madani yang taat hukum, berperadaban modern, demokratis, makmur, adil, dan bermoral tinggi dalam menyelenggarakan pelayanan kepada masyarakat secara adil dan merata, menjaga persatuan dan kesatuan bangsa dengan penuh kesetiaan kepada Pancasila dan Undang Undang Dasar Tahun 1945. Kesemuanya itu dalam rangka mencapai tujuan yang dicita-citakan oleh bangsa Indonesia (Harahap, 2017).

Buruknya penyelenggaraan manajemen Aparatur Sipil Negara selama ini juga diperparah dengan adanya politisasi birokrasi dalam ranah administrasi, yaitu intervensi pejabat politik dalam pengangkatan jabatan karier Aparatur Sipil Negara (Nuprojo, 2014). Sejarah penyelenggaraan pemerintahan Indonesia sarat dengan politisasi birokrasi, dimana kedudukan birokrasi tidak dapat bersifat netral terhadap kekuatan-kekuatan politik yang bermain dalam pemerintahan (Martini, 2010). Pengangkatan jabatan Aparatur Sipil Negara dipilih dan dipromosikan bukan berdasarkan sistem merit tetapi lebih disebabkan oleh politisasi birokrasi, bahkan pencopotan atau demosi pun juga tidak lepas dari nuansa politisasi birokrasi (Suharman, 2017).

Pembangunan manajemen Aparatur Sipil Negara untuk mewujudkan birokrasi yang profesional, berintegritas dan netral sejatinya telah dimulai sejak kebijakan Sistem Merit dalam Manajemen Aparatur Sipil Negara diamanatkan oleh Undang-Undang. UndangUndang Nomor 5 Tahun 2014 tentang Aparatur Sipil Negara adalah dasar hukum yang dengan tegas mengamanatkan bahwa instansi pemerintah harus menerapkan sistem merit dalam manajemen Aparatur Sipil Negara (Engkun, 2018). Undang-Undang Nomor 5 Tahun 2014 tersebut disusun sebagai bagian dari program reformasi birokrasi yang menjadi awal bagi pemerintah untuk melakukan manajemen sumber daya aparatur negara yang berbasis sistem merit dalam upaya meningkatkan profesionalitas, netralitas, integritas dan kinerja Aparatur Sipil Negara (Wawanudin \& Sudarno, 2018). Di dalam Undang-Undang tersebut, sistem merit didefinisikan sebagai kebijakan dan manajemen Aparatur Sipil Negara berdasarkan kualifikasi, kompetensi, dan kinerja, yang diberlakukan secara adil dan wajar tanpa diskriminasi. Tujuan akhirnya adalah untuk mewujudkan birokrasi pemerintah yang efisien, efektif, bersih, bertanggung jawab dan melayani.

Undang-Undang Aparatur Sipil Negara mencoba meletakkan beberapa perubahan dasar dalam manajemen SDM;

Pertama, perubahan dari pendekatan personel administration yang hanya berupa pencatatan administratif kepegawaian kepada human resource management yang menganggap pegawai bukan hanya sumber daya manusia yang bekerja namun juga sebagai aset negara yang harus 
dikelola, dihargai, dan dikembangkan dengan baik. Kedua, perubahan dari pendekatan closed career system yang sangat berorientasi kepada senioritas dan kepangkatan, kepada open career system yang mengedepankan kompetisi dan kompetensi Aparatur Sipil Negara dalam promosi dan pengisian jabatan.

Undang-Undang Aparatur Sipil Negara juga menempatkan pegawai Aparatur Sipil Negara sebagai sebuah profesi yang harus memiliki standar pelayanan profesi, nilai dasar, kode etik dan kode perilaku profesi, pendidikan dan pengembangan profesi, serta memiliki organisasi profesi yang dapat menjaga nilai-nilai dasar profesi

Untuk menjamin sistem merit dilaksanakan sesuai ketentuan, maka berdasarkan pasal 30 UU Nomor 5 tahun 2014, Komisi Aparatur Sipil Negara (KASN) dibentuk untuk melaksanakan fungsi pengawasan terhadap pelaksanaan norma dasar Aparatur Sipil Negara, kode etik dan kode perilaku pegawai Aparatur Sipil Negara serta penerapan sistem merit dalam kebijakan dan manajemen Aparatur Sipil Negara (Wajong, 2020).

Sesuai dengan kewenangannya, pada tahun 2018 dan 2019 Komisi Aparatur Sipil Negara (KASN) melakukan pemetaan penerapan sistem merit di instansi pemerintah (Indika, 2019). Pemetaan tersebut bertujuan untuk mengetahui tingkat penerapan sistem merit di masingmasing instansi pemerintah dan sejauh mana kesiapan instansi tersebut untuk menerapkan sistem merit sesuai ketentuan peraturan perundang-undangan. Informasi tersebut menyediakan base-line bagi penyusunan strategi dan kebijakan yang dapat mendorong semua instansi pemerintah membangun sistem merit.

Laporan hasil pemetaan penerapan sistem merit yang dirilis oleh Komisi Aparatur Sipil Negara tidak mencantumkan hasil penilaian terhadap instansi Kementerian Agama. Hal ini menarik bagi penulis untuk meneliti implementasi sistem merit dalam manajemen Aparatur Sipil Negara serta faktor-faktor yang mempengaruhi implementasinya pada Kantor Wilayah Kementerian Agama Prov. Sulawesi Selatan yang merupakan bagian dari Kementerian Agama sebagai salah satu instansi pemerintahan yang tentu saja berdasarkan peraturan perundangundangan wajib menerapkan sistem merit, namun baru-baru ini marak diberitakan terkait kasus jual beli jabatan

\section{METODE PENELITIAN}

Penelitian ini merupakan penelitian normative empiris yang akan menguji tingkat implementasi sistem merit pada Kantor Wilayah Kementerian Agama Provinsi Sulawesi Selatan dengan menggunakan kriteria yang telah ditetapkan berdasarkan Peraturan Menteri Pendayagunaan Aparatur Negara dan Reformasi Birokrasi Nomor 40 Tahun 2018 tentang Pedoman Sistem Merit dalam Manajemen Aparatur Sipil Negara.

Metode penelitian hukum normatif empiris ini pada dasarnya merupakan penggabungan antara pendekatan hukum normatif dengan adanya penambahan berbagai unsur empiris. Metode penelitian normatif-empiris mengenai implementasi ketentuan hukum normatif (undang-undang) dalam aksinya pada setiap peristiwa hukum tertentu yang terjadi dalam suatu masyarakat.

Penelitian ini menggunakan pendekatan live case study yang merupakan pendekatan pada suatu peristiwa hukum yang prosesnya masih berlangsung atau belum berakhir. Aspek penelitian hukum normatif dalam penelitian ini dilakukan berdasarkan bahan baku utama, 
menelah hal yang bersifat teoritis yang menyangkut asas-asas hukum, konsepsi hukum, pandangan dan doktrin-doktrin hukum, peraturan dan sistem hukum dengan menggunakan data sekunder, diantaranya: asas, kaidah, norma dan aturan hukum yang terdapat dalam peraturan perundang-undangan dan peraturan lainnya, dengan mempelajari buku-buku, peraturan perundang-undangan dan dokumen lain yang berhubungan erat dengan penelitian (Soekanto, 2006).

Sedangkan aspek penelitian hukum empiris dilakukan dengan meneliti secara langsung ke lapangan untuk melihat secara langsung penerapan perundang-undangan atau aturan hukum yang berkaitan dengan penegakan hukum, serta melakukan metode wawancara dan kuesioner terhadap responden yang dianggap dapat memberikan informasi mengenai permasalahan hukum tersebut.

\section{PEMBAHASAN}

A. Implementasi Sistem Merit pada Kantor Wilayah Kementerian Agama Provinsi Sulawesi Selatan

Dasar hukum penerapan sistem merit di birokrasi pemerintah Indonesia sebagai berikut:

1) Undang Undang Nomor 5 Tahun 2014 tentang Aparatur Sipil Negara (ASN);

2) Peraturan Presiden Nomor 11 Tahun 2017 tentang Manajemen Pegawai Negeri Sipil (PNS);

3) Peraturan Menteri Pendayagunaan Aparatur Negara dan Reformasi Birokrasi Nomor 40 Tahun 2018 tentang Pedoman Sistem Merit dalam Manajemen Aparatur Sipil Negara (ASN);

4) Peraturan Komisi Aparatur Sipil Negara Nomor 9 Tahun 2019 tentang Tata Cara Penilaian Mandiri Sistem Merit dalam Manajemen Aparatur Sipil Negara di Lingkungan Instansi Pemerintah sebagai perbaikan dari Peraturan Ketua Komisi Aparatur Sipil Negara Nomor 5 Tahun 2017 tentang Penilaian Mandiri Penerapan Sistem Merit dalam Manajemen Aparatur Sipil Negara di Instansi Pemerintah

Berdasarkan Peraturan Menteri Pendayagunaan Aparatur Negara Nomor 40 Tahun 2018 tentang pedoman sistem merit dalam Manajemen Aparatur Sipil Negara, terdapat 8 kriteria sistem merit yang harus dimplemetasikan oleh instansi pemerintah yakni

1) Mempunyai rencana kebutuhan ASN untuk 5 tahun yang dirinci menurut jenis dan jenjang jabatan dan disusun berdasarkan Analisa Jabatan (disusun berdasarkan Anjab dan $\mathrm{ABK})$, dengan mempertimbangkan pegawai yang memasuki masa pensiun

2) Melakukan rekrutmen pegawai secara terbuka dan kompetitif, baik dari jalur CPNS, PPPK, dan juga dari PNS yang berasal dari instansi lain.

3) Mempunyai kebijakan dan program pengembangan karier yang dimulai dengan pemetaan talenta, analisis kesenjangan kompetensi dan kesenjangan kinerja,strategi dan program untuk mengatasi kesenjangan, serta pembentukan talent pool dan rencana suksesi.

4) Menerapkan manajemen kinerja yang dimulai dengan penetapan target kinerja, evaluasi kinerja secara berkala dengan menggunakan metode yang obyektif, menganalisis kesenjangan kinerja, dan mempunyai strategi untuk mengatasinya.

5) Mengaitkan kebijakan penggajian, pemberian penghargaan, dan promosi dengan kinerja dan disiplin. 
6) Melaksanakan promosi, mutasi secara obyektif dan transparan didasarkan pada kesesuaian kualifikasi, kompetensi dan kinerja dengan memanfaatkan talent pool.

7) Memberi perlindungan agar pegawai dapat melaksanakan tugas dengan baik dan memberi pelayanan kepada publik.

8) Mempunyai sistem pendukung seperti sistem informasi kepegawaian yang terintegrasi, assessment center, dan aplikasi lainnya yang mendukung pelaksanaan manajemen ASN.

Berdasarkan data hasil pengamatan dan wawancara di Kantor Wilayah Kementerian Agama Provinsi Sulawesi Selatan dengan berpedoman pada 8 aspek dalam kriteria penilaian penerapan sistem merit dalam manajemen aparatur sipil negara, dapat dipaparkan hasil sebagai berikut:

1. Aspek Perencanaan Kebutuhan

a. Sub Aspek; Ketersediaan peta jabatan dan rencana kebutuhan pegawai untuk jangka menengah 5 (lima) tahun yang disusun menurut jumlah, jabatan, pangkat, kualifikasi, kompetensi dan unit kerja sesuai dengan rencana strategis organisasi dan ditetapkan PPK.

Berdasarkan data yang didapatkan, Kanwil Kementerian Agama Prov. Sulawesi Selatan telah memiliki peta jabatan dan rencana kebutuhan pegawai untuk jangka menengah berdasarkan analisis jabatan dan analisis beban kerja.

b. Sub Aspek; Ketersediaan database pegawai secara lengkap dan up to date yang disusun menurut jumlah, jabatan, pangkat, unit kerja, kualifikasi dan kompetensi.

Berdasarkan data yang didapatkan, Kanwil Kementerian Agama Prov. Sulawesi Selatan telah memiliki sistem informasi kepegawaian yang memuat data pegawai dan dikelola secara up to date.

c. Sub Aspek; Ketersediaan database pegawai yang akan memasuki masa pensiun dalam 5 (lima) tahun yang disusun menurut jumlah, jabatan, pangkat dan unit kerja;

Berdasarkan data yang didapatkan, Kanwil Kementerian Agama Prov. Sulawesi Selatan telah memiliki data rinci pegawai yang akan pensiun dalam 5 (lima) tahun kedepan berbasis sistem informasi kepegawaian.

d. Sub Aspek; Ketersediaan rencana pemenuhan kebutuhan pegawai untuk jangka menengah ( 5 lima tahun), baik yang berasal dari CPNS, PNS instansi lainnya, PPPK ataupun anggota TNI dan Polri untuk instansi tertentu;

Berdasarkan data yang didapatkan, Kanwil Kementerian Agama Prov. Sulawesi Selatan telah memiliki rencana pemenuhan kebutuhan pegawai untuk jangka menengah ( 5 lima tahun) namun hanya melalui jalur pengadaan CPNS.

2. Aspek Pengadaan

a. Sub Aspek; Ketersediaan rencana pengadaan pegawai untuk tahun berjalan yang dirinci menurut jumlah, jabatan, pangkat, kualifikasi, kompetensi, dan unit kerja, baik yang berasal dari CPNS, PNS dari instansi/daerah lain, PPPK ataupun anggota TNI dan Polri untuk instansi tertentu;

Berdasarkan data yang didapatkan, Kanwil Kementerian Agama Prov. Sulawesi Selatan setiap tahun mengirimkan usul penetapan formasi pengadaan CPNS setelah moratorium pengadaan CPNS dan melakukan proses seleksi untuk tahun 2018 dan 2019.

b. Sub Aspek; Ketersediaan kebijakan internal instansi terkait pelaksanaan pengadaan pegawai ASN secara terbuka, kompetitif, transparan dan tidak diskriminatif; 
Berdasarkan data yang didapatkan, dalam melaksanakan seleksi CPNS, Kanwil Kementerian Agama Prov. Sulawesi Selatan berpedoman pada petunjuk teknis yang ditetapkan oleh Biro Kepegawaian Sekertariat Jenderal Kementerian Agama RI.

c. Sub Aspek; Pelaksanaan penerimaan CPNS, PPPK atau PNS dari instansi lain dilakukan secara terbuka;

Berdasarkan data yang didapatkan, dalam melaksanakan seleksi CPNS, Kanwil Kementerian Agama Prov. Sulawesi Selatan memanfaatkan website resmi dalam penyampaian informasi penerimaan CPNS.

d. Sub Aspek; Pelaksanaan Pelatihan Prajabatan/Pelatihan Dasar bagi CPNS;

Berdasarkan data yang didapatkan, pelaksanaan pelatihan prajabatan /pelatihan dasar CPNS Kanwil Kementerian Agama Prov. Sulawesi Selatan dilaksanakan oleh Balai Diklat Keagamaan Makassar dan waktu pelaksanaannya menyesuaikan dengan ketersediaan anggaran.

e. Sub Aspek; Persentase pegawai yang baru diangkat menjadi PNS yang penempatan pertamanya sesuai jabatan yang dilamar;

Berdasarkan data yang didapatkan, penempatan CPNS Kanwil Kementerian Agama Prov. Sulawesi Selatan 100 persen sesuai dengan formasi jabatan yang dilamar.

3. Aspek Pengembangan Karir

a. Sub Aspek; Ketersediaan standar kompetensi manajerial, teknis, dan sosial-kultural untuk setiap jabatan dengan keputusan PPK;

Berdasarkan data yang didapatkan, Kanwil Kementerian Agama Prov. Sulawesi Selatan memiliki standar kompetensi manajerial, teknis, dan sosial-kultural untuk setiap jabatan yang ditetapkan oleh Kementerian Agama Pusat.

b. Sub Aspek; Ketersediaan informasi tentang profil pegawai melalui pemetaan talenta yang dilakukan oleh lembaga penilai yang terakreditasi atau tim asesor yang bersertifikat;

Berdasarkan data yang didapatkan, Kanwil Kementerian Agama Prov. Sulawesi Selatan pernah melakukan pemetaan kompetensi pegawai namun hanya terbatas kepada pegawai yang telah menduduki jabatan dan beberapa pegawai yang dipersiapkan untuk menduduki jabatan sehingga belum memiliki profil kompetensi seluruh pegawai.

c. Sub Aspek; Pembangunan talent pool dan rencana suksesi yang disusun berdasarkan profil ASN dengan mempertimbangkan pola karir instansi;

Berdasarkan data yang didapatkan, Kanwil Kementerian Agama Prov. Sulawesi Selatan belum menerapkan pembangunan talent pool dan rencana suksesi yang disusun berdasarkan profil ASN dengan mempertimbangkan pola karir.

d. Sub Aspek; Ketersediaan informasi tentang kesenjangan kualifikasi dan kompetensi dengan membandingkan antara profil pegawai dan standar kompetensi jabatan;

Berdasarkan data yang didapatkan, Kanwil Kementerian Agama Prov. Sulawesi Selatan belum menyediakan informasi tentang kesenjangan kualifikasi dan kompetensi dengan membandingkan antara profil pegawai dan standar kompetensi jabatan untuk semua pegawai. Hasil pemetaan kompetensi juga tidak dipublikasikan bahkan pegawai yang telah mengikuti pemetaan kompetensi tidak mengetahui hasil pemetaan kompetensi yang dimilikinya.

e. Sub Aspek; Ketersediaan informasi tentang kesenjangan kinerja dengan membandingkan antara kinerja yang diharapkan dan kinerja sebenarnya; 
Berdasarkan data yang didapatkan, Kanwil Kementerian Agama Prov. Sulawesi Selatan belum melaksanakan analisis kesenjangan kinerja untuk seluruh pegawai.

f. Sub Aspek; Ketersediaan strategi dan program peningkatan kompetensi dan kinerja yang disusun berdasarkan analisis kesenjangan kompetensi dan kesenjangan kinerja; Berdasarkan data yang didapatkan, Kanwil Kementerian Agama Prov. Sulawesi Selatan belum menyusun strategi dan program peningkatan kompetensi dan kinerja yang disusun berdasarkan analisis kesenjangan kompetensi dan kesenjangan kinerja.

g. Sub Aspek; Penyelenggaraan pendidikan dan pelatihan untuk mengatasi kesenjangan;

Berdasarkan data yang didapatkan, Kanwil Kementerian Agama Prov. Sulawesi Selatan belum melaksanakan analisis kesenjangan analisis kesenjangan kompetensi dan kinerja sesuai kebutuhan individu, pelaksanaan pendidikan dan pelatihan selama ini hanya berdasarkan pemenuhan kuota dengan mengikuti persyaratan peserta yang ditetapkan oleh penyelenggara pendidikan dan pelatihan.

h. Sub Aspek; Pelaksanaan program peningkatan kompetensi melalui praktik kerja dan pertukaran pegawai;

Berdasarkan data yang didapatkan, Kanwil Kementerian Agama Prov. Sulawesi Selatan belum menyusun program pengembangan karir melalui praktik kerja dan pertukaran pegawai.

i. Sub Aspek; Pelaksanaan program peningkatan kompetensi melalui coaching, counselling, dan mentoring;

Berdasarkan data yang didapatkan, Kanwil Kementerian Agama Prov. Sulawesi Selatan belum melaksanakan kegiatan peningkatan kompetensi melalui coaching, counselling, dan mentoring secara formal.

4. Aspek Promosi dan Mutasi

a. Sub Aspek; Ketersediaan kebijakan internal instansi tentang pola karier;

Berdasarkan data yang didapatkan, Kementerian Agama belum memiliki kebijakan internal instansi tentang pola karier.

b. Sub Aspek; Ketersediaan kebijakan internal tentang pengisian JPT secara terbuka serta promosi dan mutasi dengan mengacu pada talent pool dan rencana suksesi;

Berdasarkan data yang didapatkan, Kementerian Agama telah menyusun dan menetapkan kebijakan internal untuk mutasi, rotasi dan promosi ke JPT, administrator dan pengawas dan Kanwil Kementerian Agama Prov. Sulawesi Selatan menerapkannya sesuai dengan batas kewenangan yang dimiliki.

c. Sub Aspek; Pelaksanaan pengisian JPT, Jabatan Administrator dan Jabatan Pengawas secara terbuka dan kompetitif.;

Berdasarkan data yang didapatkan, Kanwil Kementerian Agama Prov. Sulawesi Selatan sesuai dengan kewenangan yang dimiliki terkait pengisian jabatan administrator dan pengawas telah menggunakan metode asesmen kompetensi namun belum membuka seluas-luasnya kesempatan kepada pegawai untuk mengikutinya.

5. Manajemen Kinerja

a. Sub Aspek; Penyusunan kontrak kinerja yang terukur dan diturukan dari Rencana Strategis organisasi; 
Berdasarkan data yang didapatkan, Kanwil Kementerian Agama Prov. Sulawesi Selatan sudah menyusun kontrak kinerja bagi seluruh pegawai yang diturunkan dari Rencana Strategis organisasi.

b. Sub Aspek; Penerapan metode penilaian kinerja yang obyektif dan terukur; Berdasarkan data yang didapatkan, Kanwil Kementerian Agama Prov. Sulawesi Selatan belum menerapkan metode penilaian kinerja yang obyektif dan terukur untuk seluruh pegawai.

c. Sub Aspek; Pelaksanaan penilaian kinerja secara berkala yang disertai dengan dialog kinerja untuk memastikan tercapainya kontrak kinerja;

Berdasarkan data yang didapatkan, Kanwil Kementerian Agama Prov. Sulawesi Selatan belum melaksanakan penilaian kinerja secara berkala 3 (tiga) bulan sekali yang disertai dengan dialog kinerja.

d. Sub Aspek; Ketersediaan informasi tentang analisis permasalahan kinerja dan strategi penyelesaiannya untuk mencapai tujuan organisasi;

Berdasarkan data yang didapatkan, Kanwil Kementerian Agama Prov. Sulawesi Selatan belum menganalisis permasalahan dan menyusun strategi untuk mengatasi masalah kinerja yang rendah serta melaksanakan strategi tersebut untuk mewujudkan tujuan organisasi.

e. Sub Aspek; Penggunaan hasil penilaian kinerja sebagai dasar bagi penentuan keputusan manajemen terkait pembinaan dan pengembangan karier (promosi, mutasi, demosi, rotasi, diklat);

Berdasarkan data yang didapatkan, Kanwil Kementerian Agama Prov. Sulawesi Selatan belum mendasari hasil penilaian kinerja sebagai pertimbangan dalam pengembangan karir (promosi, rotasi, demosi, diklat, praktik kerja dan pertukaran pegawai).

6. Penggajian, Penghargaan, dan Disiplin

a. Sub Aspek; Ketersediaan kebijakan internal instansi tentang pembayaran tunjangan kinerja berdasarkan hasil penilaian kinerja;

Berdasarkan data yang didapatkan, Kanwil Kementerian Agama Prov. Sulawesi Selatan belum menerapkan perhitungan hasil penilaian kinerja sebagai dasar pembayaran tunjangan kinerja. Tunjangan kinerja selama ini dibayarkan hanya berdasarkan faktor disiplin kerja.

b. Sub Aspek; Ketersediaan kebijakan internal instansi tentang penghargaan terhadap pegawai berprestasi luar biasa; (Moonti, et.al, 2018).

Berdasarkan data yang didapatkan, Kanwil Kementerian Agama Prov. Sulawesi Selatan belum menetapkan kebijakan internal dan belum pernah memberikan penghargaan kepada pegawai berprestasi luar biasa.

c. Sub Aspek; Ketersediaan kebijakan internal instansi tentang penegakan disiplin, kode etik dan kode perilaku pegawai ASN di lingkungan instansinya;

Berdasarkan data yang didapatkan, Kanwil Kementerian Agama Prov. Sulawesi Selatan telah memiliki kode etik dan kode perilaku yang ditetapkan oleh Kementerian Agama pusat namun belum membentuk tim dalam rangka penegakan kode etik dan kode perilaku secara konsisten.

d. Sub Aspek; Pengelolaan data terkait pelanggaran disiplin, pelanggaran kode etik dan kode perilaku yang dilakukan pegawai ASN;

Berdasarkan data yang didapatkan, Kanwil Kementerian Agama Prov. Sulawesi Selatan belum mempunyai database terkait penegakan disiplin, pelanggaran kode 
etik dan kode perilaku yang terintegrasi dengan Sistem Informasi Kepegawaian Nasional (BKN).

7. Perlindungan dan Pelayanan

a. Sub Aspek; Kebijakan dan pelaksanaan perlindungan pegawai diluar dari jaminan kesehatan, jaminan kecelakaan kerja, program pensiun, yang diselenggarakan secara nasional.

Berdasarkan data yang didapatkan, Kanwil Kementerian Agama Prov. Sulawesi Selatan belum menyusun dan menetapkan kebijakan perlindungan hukum, program persiapan pensiun, serta program perlindungan lainnya.

b. Sub Aspek; Penyediaan fasilitas yang memberi kemudahan bagi pegawai ASN yang membutuhkan pelayanan administrasi;

Berdasarkan data yang didapatkan, Kanwil Kementerian Agama Prov. Sulawesi Selatan telah membentuk pelayanan terpadu satu pintu dalam rangka memudahkan akses layanan administrasi.

8. Sistem Informasi

a. Sub Aspek; Pembangunan Sistem Informasi Kepegawaian yang berbasis teknologi informasi yang terintegrasi dengan sistem penilaian kinerja, penegakan disiplin dan pembinaan pegawai;

Berdasarkan data yang didapatkan, sistem informasi kepegawaian yang dimiliki Kanwil Kementerian Agama Prov. Sulawesi Selatan belum terintegrasi dengan sistem penilaian kinerja, penegakan disiplin dan pembinaan pegawai.

b. Sub Aspek; Penerapan sistem penilaian kinerja berbasis teknologi informasi yang terintegrasi dengan Sistem Informasi Kepegawaian;

Berdasarkan data yang didapatkan, Kanwil Kementerian Agama Prov. Sulawesi Selatan belum menerapkan sistem penilaian kinerja (e-performance) yang terintegrasi dengan Sistem Informasi Kepegawaian.

c. Sub Aspek; Penerapan e-office yang memudahkan pelayanan administrasi kepegawaian;

Berdasarkan data yang didapatkan, Kanwil Kementerian Agama Prov. Sulawesi Selatan belum menggunakan e-office yang memudahkan pelayanan administrasi kepegawaian dan pelayanan lainnya.

d. Sub Aspek; Pembangunan dan penggunaan asessment centre dalam pemetaan kompetensi dan pengisian jabatan berbasis teknologi informasi;

Berdasarkan data yang didapatkan, Kanwil Kementerian Agama Prov. Sulawesi Selatan belum membangun dan menggunakan assessment center untuk pembinaan karir seluruh pegawai.

B. Faktor-Faktor Yang Mempengaruhi Implementasi Sistem Merit pada Kantor Wilayah Kementerian Agama Provinsi Sulawesi Selatan

1. Faktor Hukumnya sendiri

Substansi hukum menjadi salah satu hal yang mempengaruhi implementasi kebijakan atau peraturan pada Kantor Wilayah Kementerian Agama Provinsi Sulawesi Selatan. Hal ini dipersepsikan sebagai akibat dari tumpang tindihnya aturan terkait aparatur sipil negara yang masih dirasakan dan diperparah dengan kurangnya sosialisasi yang massif dari pemangku kebijakan

2. Faktor Penegak Hukum 
Kewenangan pengawasan dan penindakan yang dimiliki oleh stake holder tidak berjalan dengan baik, sehingga terkesan ada pembiaran terhadap pelanggaran-pelanggaran yang terjadi.

3. Faktor sarana atau fasilitas yang mendukung penegakan hukum Kurangnya fasilitas dan SDM yang mendukung implementasi kebijakan juga masih terjadi dan berakibat menghambat penerapan kebijakan.

4. Faktor masyarakat

Implementasi sebuah kebijakan juga harus mendapatkan dukungan dari masyarakat termasuk seringnya intervensi politik menjadi hambatan penerapan kebijakan

5. Faktor kebudayaan

Hal-hal yang selama ini langgeng, baik oleh aparat maupun masyarakat masih sering dipertahankan meskipun telah ada aturan atau regulasi terbaru sehingga menghambat implementasi kebijakan.

6. Faktor profesionalisme

Sumber Daya Manusia Aparatur Sipil Negara yang tidak didukung upaya peningkatan kompetensi menjadi penghambat implementasi kebijakan.

\section{KESIMPULAN}

Dari hasil penelitian didapatkan bahwa dari delapan aspek dan 35 sub aspek yang dijadikan indikator dalam melihat impelementasi sistem merit pada Kantor Wilayah Kementerian Agama Provinsi Sulawesi Selatan, terdapat 12 sub aspek yang terimpelementasi, 5 sub aspek yang dinilai kurang terimplementasi, dan 18 sub aspek yang tidak terimplementasi. Sehingga dapat disimpulkan bahwa secara kualitatif, sistem merit sebagaimana yang diamanatkan dalam Undang-Undang Nomor 5 Tahun 2014 beserta berbagai regulasi turunannya kurang terimplementasi pada Kantor Wilayah Kementerian Agama Provinsi Sulawesi Selatan. Hal ini dipengaruhi oleh berbagai faktor terkait substansi regulasi, peran stake holder, kurangnya fasilitas pendukung, dukungan masyarakat, budaya dan profesionalisme sumber daya manusia yang perlu ditingkatkan.

\section{SARAN}

Penerapan sistem merit dalam manajemen Aparatur Sipil Negara di instansi pemerintah merupakan sebuah sistem yang sangat penting untuk dilakukan sebagai upaya untuk terciptanya birokrasi yang sehat, efektif dan efisien. Instansi pemerintah pada umumnya dan Kantor Wilayah Kementerian Agama Provinsi Sulawesi Selatan khususnya harus berbenah dalam menjawab tantangan undang-undang dalam mengimplemetasikan sistem merit sebagai bagian dari upaya reformasi birokrasi dalam mewujudkan tata kelola pemeritahan yang baik. Harmonisasi regulasi, optimalisasi pengawasan, dukungan fasilitas, sosialisasi yang masif ke masyarakat, dan peningkatan kompetensi sumber daya manusia adalah langkahlangkah pembenahan yang harus diambil dengan mewujudkannya dalam program-program yang konkret dalam rangka mengimplementasikan sistem merit sebagaimana amanat undang-undang 


\section{DAFTAR PUSTAKA}

Engkun, T. A. (2018). Rancang Bangun Manajemen Karier PNS. Jurnal Inspirasi, 9(2), 47-62.

Fernanda, D. (2005). Konflik Kewenangan Pengelolaan Kepelabuhanan dalam Perspektif Sistem Administrasi Pemerintahan dan Otonomi Daerah di Indonesia. Jurnal Borneo Administrator, 1(3), 32-56

Harahap, N. A. (2017). Perlindungan Hukum Bagi Aparatur Negara Dalam Penyelesaian Sengketa Kepegawaian Pasca Berlakunya Undang-Undang Nomor 5 Tahun 2014 Tentang Aparatur Sipil Negara. Jurnal Yuridis, 3(2), 17-32.

Indika, A. (2019). Perlindungan Hukum Terhadap Pegawai Negeri Sipil Akibat Pelanggaran Sistem Merit Pada Proses Pengisian Jabatan Pimpinan Tinggi. Jurist-Diction, 2(5), 15591574 .

Martini, R. (2010). Politisasi birokrasi di Indonesia. POLITIKA Jurnal Ilmu Politik MIP, 1(1), 6774 .

Moonti, R. M., Ismail, N., Karepoan, J. K., \& Djanggih, H. (2018). Pelaksanaan Pengukuran Prestasi Kerja Terhadap Aparatur Sipil Negara (ASN) di Dinas Pertanian Provinsi Gorontalo. Jurnal Ilmiah Kebijakan Hukum, 12(2), 151-161.

Nurprojo, I. S. (2014). Merit System dan Politik Birokrasi di Era Otonomi Daerah. Civil Service Journal, 8(1 Juni), 45-52

Sirait, B. C. (2018). Memotret E-Procurement dalam Mewujudkan Good Governance di Indonesia. Journal of Governance, 3(1), 18-34

Soekanto, S. (2006). Pengantar penelitian hukum. Penerbit Universitas Indonesia (UI-Press).

Suharman, E. (2017). Kewenangan Pejabat Pembina Kepegawaian dalam Pengisian Jabatan Pimpinan Tinggi Pratama di Daerah Menurut Undang-undang Nomor 5 Tahun 2014 Tentang Aparatur Sipil Negara. Jurnal IUS Kajian Hukum dan Keadilan, 5(2), 219-232.

Wajong, M. A. P. (2020). Tugas Dan Wewenang Komisi Aparatur Sipil Negara Menurut Undang-Undang Nomor 5 Tahun 2014 Tentang Aparatur Sipil Negara. Lex AdministratuM, 7(2), 23-31

Wawanudin, W., \& Sudarno, R. (2018). Pelaksanaansistem Merit dalam UU Asn, Wewenang Kasn dan Analisis Peraturan Perundang-undangan yang Berpengaruh terhadap Wewenang Kasn. Jurnal MoZaiK, 10(1), 26-40.

Yudiatmaja, W. E. (2015). Politisasi Birokrasi: Pola Hubungan Politik dan Birokrasi di Indonesia. Jurnal Ilmu Administrasi Negara (JUAN), 3(1), 10-28.

Zuhro, R. S. (2016). Reformasi Birokrasi Lokal Melalui Pelayanan Terpadu. Jurnal Penelitian Politik, 5(1), 31-45. 